\section{"MORTO PELAS MÃOS DO POVO": RITUAIS DE EXECUÇÃO E JUSTIÇA POPULAR NA ANTIGUIDADE TARDIA}

* Universidade de São Paulo, São Paulo, Brasil.

RESUMO: O linchamento, enquanto prática da justiça popular, tinha uma longa tradição no mundo romano. Sua constante referência nas fontes textuais da Antiguidade Tardia, porém, parece indicar uma preocupação nova das autoridades e dos autores antigos com suas consequências políticas. $\mathrm{O}$ objetivo deste estudo consiste em analisar as características dos linchamentos nas cidades mediterrâneas dos séculos IV e V levando-se em consideração a relação entre justiça popular e justiça oficial, os mecanismos e processos que mais frequentemente conduziam ao linchamento e os objetivos, alvos e motivaçōes dos participantes. Pretende-se demonstrar, em primeiro lugar, como a concepção de "morte justa", que subjaz a todas as formas de linchamento, ainda revelava a permanência nas cidades do Mediterrâneo das antigas noções de cidadania e de direitos do povo. Ao mesmo tempo, porém, pretende-se sublinhar como o impacto e a ressonância políticas do recurso frequente a esses rituais informais de execução haviam sido modificados (e amplificados) no Império Romano Tardio, tornando-se uma das formas mais características de confronto político no período.

PALAVRAS-CHAVE: Linchamentos; violência coletiva; confronto político; Antiguidade Tardia

"MURDERED BY THE HANDS OF THE PEOPLE": RITES OF EXECUTION AND POPULAR JUSTICE IN LATE ANTIQUITY

ABSTRACT: As a practice of popular justice, executions by lynching had a long tradition in the Roman world. Nevertheless, the constant reference in the textual sources of Late Antiquity to this kind of collective violence seems to indicate 
1. Ver, por exemplo, as diferentes opinióes de Jones; Martindale; Morris (1980, p. 594); Delmaire; Lepelley (1983, p. 473) e Shaw (2011, p. 50). a new concern of authorities and ancient authors with its political consequences. The aim of this study is to analyze the characteristics of lynching in the Mediterranean cities of the fourth and fifth centuries taking into account the relationship between official and popular justice, the mechanisms and processes that most often led to the lynching and the objectives, targets and motivations of the participants. It is intended to demonstrate, on the one hand, how the conception of "fair death" which underlies all forms of lynching revealed the permanence in the Mediterranean cities of the ancient notions of citizenship and rights of the people. On the other hand, it aims to highlight how the impact and political resonance of the frequent use of these informal rituals of execution had been modified (and amplified) in the Late Roman Empire, becoming one of the most characteristic forms of political confrontation in the period.

KEYWORDS: Lynching; collective violence; contentious politics; Late Antiquity

Em meados do século V, um cronista gaulês, relatando os eventos mais marcantes do Império Romano de 379 a 452, incluiu entre as notícias referentes aos anos de 408 e 409 o destino trágico do comandante dos exércitos africanos: Ioannes comes Africae occisus a populo est; "João, o comandante da África, foi morto pelo povo" (Chronica Gallica a. 452, n. 59, 15). Pouco sabemos sobre esse episódio e até mesmo a data a ele atribuída nessa fonte tem dado margem a controvérsias. ${ }^{1}$ Mas é significativo que o cronista o tratasse como um fato comum o bastante para dispensar maiores explicações e digno de nota o suficiente para ser mencionado, entre o assassinato do regente do Império do Ocidente, Estilicão, e as devastações provocadas por saxões, vândalos e alanos, como um evento político de primeira importância. Ser "morto pelas mãos do povo" era, com efeito, um risco que qualquer liderança no mundo romano poderia correr, sempre que sua imagem fosse associada à de um inimigo público. Nesse sentido, o assassinato relatado pelo cronista gaulês de 452 poderia ser visto como apenas um elo numa longa tradição. Mas de que forma eventos como esse podem iluminar as concepçóes populares e a prática política na Antiguidade Tardia? 
Durante muito tempo, os linchamentos mais espetaculares do período, como o da filósofa pagã Hipátia em Alexandria, foram vistos isoladamente e interpretados como um fenômeno novo e representativo da crescente intolerância religiosa na Antiguidade Tardia (DZIELSKA, 1996). Mais recentemente, muitos estudiosos têm buscado redimensionar a novidade representada por essas execuçôes específicas, vendo-as como parte de um padrão de ação mais geral e aceito no período (HAAS, 1997, p. 87-90; HAHN, 2004, p. 110-20; WATTS, 2006; LAVAN, 2011, p. xv-xvi). Reconhecer a existência desse repertório comum e sua adaptação por diferentes grupos para resolver conflitos particulares é, sem dúvida, um passo importante se queremos compreeder esse fenômeno em seu contexto histórico, social e cultural mais amplo. Mas para entendermos as razões do recurso recorrente a esses "ritos de violência" e seus significados para seus participantes é ainda preciso ir além.

$\mathrm{Na}$ sequência de trabalhos sobre a violência popular em outros períodos históricos, como os de Corbin (1990), Davis (1990), Pfeifer (2004) e outros, o que pretendo fazer nesta ocasião é estudar as características dos linchamentos na Antiguidade Tardia levando em consideração a relação entre justiça popular e justiça oficial, os mecanismos e processos que mais frequentemente conduziam ao linchamento e os objetivos, alvos e motivaçóes dos participantes. $\mathrm{O}$ argumento que sustento neste texto é o de que, embora a concepção de "morte justa" que subjaz a todas as formas de linchamento revele a permanência durante os séculos IV e V de uma "abertura pública" e das antigas noções de cidadania e de direitos do povo nas cidades do Mediterrâneo, o impacto e a ressonância política dessa forma letal de justiça popular foram modificados (e ampliados) pelas novas circunstâncias do Império Romano Tardio, tornando-se uma das formas mais características de confronto político no período.

\section{UM REPERTÓRIO CONHECIDO}

Linchamento é um termo genérico para designar toda forma de execução coletiva, informal e ritualizada, de um ou mais indivíduos tidos pelo grupo como culpados óbvios e passíveis de uma punição imediata. À diferença, porém, da expe- 
riência histórica da fronteira americana que deu ao fenômeno o seu nome (WALDREP, 2002, p. 13-25), o linchamento em Roma e em outras sociedades do Mediterrâneo antigo ocorria apenas em circunstâncias que suscitavam a indignação (NIPPEL, 1995, p. 42). Não se tratava, portanto, da imposição corriqueira e sistemática da supremacia étnica ou de classe e ainda menos da ação permanente de pelotôes de vigilância ou de grupos de extermínio. Outra diferença é que, enquanto os linchamentos no sul, oeste e meio-oeste dos Estados Unidos ganharam força após 1860 como uma reação às reformas do sistema de justiça criminal, com sua racionalidade burguesa, asséptica e impessoal (PFEIFER, 2004), os rituais de execução informais no mundo romano não derivavam de um princípio legal distinto da ordem estabelecida. Não se constituíram em oposição aos procedimentos legais correntes, mas como forma de antecipar-se à lei e de executá-la por conta própria (NIPPEL, 1995, p. 42-6).

A prática do linchamento em Roma e no mundo romano pode ser vista, em primeiro lugar, como uma consequência direta da inexistência de um aparato policial e da aceitação na própria lei romana do princípio da autoproteção (FAGAN, 2011, p. 478). Desde a Lei das Doze Tábuas, por volta de 450 a.C., a responsabilidade por trazer um réu a julgamento competia ao próprio interessado, que podia, para isso, recorrer à força, se preciso fosse (Lei das Doze Tábuas, I, 2; III, 2). O uso da violência para repelir a violência (uim ui repellere licet: Dig. 43, 16, 1, 27) e a vingança sumária de uma ofensa privada eram práticas socialmente aceitas e consolidadas no próprio pensamento jurídico (FAGAN, 2011, p. 484). Mas nem todas as formas de linchamento se enquadravam no âmbito da resolução privada de conflitos, pois, em muitos casos, a execução coletiva era apresentada como uma punição pública e no interesse de todos. Nesse sentido, o linchamento também pode ser visto, como Wilfried Nippel já argumentou, como um aspecto do caráter público dos processos decisórios durante a República romana e, mais tarde, do papel da aclamação na legitimação do imperador (NIPPEL, 1995, p. 46).

$\mathrm{O}$ linchamento entre os romanos não pressupunha, de fato, uma concepção de justiça diferente daquela que havia fundado o próprio processo público legal durante a República como um iudicium populi. Uma vez que o "crime" era 
definido como aquilo que a comunidade considerava como um atentado ao interesse público, a própria comunidade podia se sentir autorizada a tomar a lei em suas próprias mãos (HARRIES, 2007, p. 131). Desde o final do período republicano, os rituais populares de execução em Roma também foram muitas vezes legitimados como de interesse público pelo apoio informal da própria elite dirigente, como no caso do tribuno Saturnino e de seus companheiros em 100 a.C. (Apiano, BCiv I, 32, 145; Floro II, 4, 5-6), ou mesmo por decisões oficiais, como as associadas às proscrições da época de Sila (Agostinho, De civ. Dei, III, 28; HINARD, 1984, p. 303-7). Após o estabelecimento do Principado, quando a condenação à morte deixou de ser uma deliberação coletiva para ser uma atribuição exclusiva do imperador na capital e de seus representantes nas províncias, a participação popular nos rituais de execração dos condenados por "traição" continuou a ser requisitada como uma forma de confirmar a validade da justiça imperial (DAVID, 1984, p. 171-5). Compreendendo essa participação como um direito, tanto os soldados como a plebe reunida nos lugares de espetáculo podiam reclamar dos imperadores a cabeça de um funcionário imperial indesejado (Tácito, Hist. III, 74, 2), enquanto que os próprios imperadores, ainda que mantendo oficialmente o monopólio da vingança legítima (RIVIÈRE, 2006), podiam entregar à morte pelas mãos do povo eventuais ameaças ao seu governo, sob a alegação de apenas cumprir a "vontade popular" (Suetônio, Caligula, 28). A mesma dinâmica pode ser observada nas províncias na condescendência com que muitos governadores podiam tratar linchamentos ocasionais, como os de cristãos (Tertuliano, Apol. 37, 2).

Enquanto forma de execução, o linchamento também não diferia, em seu princípio, da aplicação das penas oficiais. No sistema penal romano, o objetivo primeiro de qualquer punição era vingar a ofensa praticada, retribuindo ao condenado um sofrimento proporcional ao dano por ele provocado. Isso significa que a pena de morte não deveria apenas privar o culpado de sua vida, mas ser tão dolorosa quanto possível no caso dos piores tipos de culpados (COLEMAN, 1990, p. 46). $\mathrm{O}$ sofrimento físico e a publicidade da pena também tinham como objetivo humilhar e degradar o condenado, alienando-o de seu contexto social e tornando-o objeto de ridículo 
(COLEMAN, 1990, p. 47; WIEDEMANN, 1992, p. 71-2). Para o Estado romano, a justificativa para punir seus cidadãos de forma pública e dolorosa era que eles o mereciam e que o espetáculo do terror seria salutar como uma forma de exemplo para outros (HARRIS, 1999, p. 144-5). O linchamento, do mesmo modo, também envolvia o sofrimento, a humilhação e a desonra de sua vítima e expressava a mesma expectativa de uma justiça cruel e exemplar. Apesar disso, as execuçōes coletivas informais entre os romanos jamais se constituíram, à diferença, mais uma vez, do caso americano (PFEIFER, 2004, p. 44-9), como uma paródia dos tribunais oficiais ou do patíbulo. Não imitavam a ação individual do carrasco ou os suplícios previstos em lei, mas seguiam sempre uma forma própria, coletiva e específica, de punição.

Entre os gregos, o principal modo de execução informal por uma multidão era o apedrejamento até a morte (GRAS, 1984; ROSIVACH, 1987; FORSDYKE, 2008, p. 37-41). Entre os romanos, o apedrejamento não era desconhecido (especialmente entre os militares: Lívio, IV, 50, 5-6; Plutarco, Sull. 6, 9), mas sua principal forma de demonstrar que uma execução coletiva era um ato de justiça popular consistia em esquartejar a vítima com as mãos, manibus discerpere (NIPPEL, 1995, p. 43-4). O esquartejamento, como a lapidação, implicava um mesmo desejo de participação coletiva na aplicação da justiça e a aceitação da responsabilidade por parte de todos os participantes pela morte que executavam. Mas a mutilação do cadáver (ou mesmo da vítima ainda viva), que é característica desse tipo de linchamento, revela ainda objetivos mais específicos. Como François Hinard ressaltou a respeito das proscriçôes da época de Sila, a mutilação coletiva e gradativa de um corpo ainda vivo, como o de M. Mário Gratidiano (Floro, II, 9, 26; Agostinho, De civ. Dei, III, 28), revelava menos a intenção de torturá-lo do que a de torná-lo irreconhecível até mesmo para a própria vítima (HINARD, 1984, p. 309). Enquanto ritual de desonra e humilhação, a execução informal por uma multidão, como a destruição de estátuas, que era seu simulacro, expressava sempre um desejo de revanche e a inversão de papéis entre o poderoso e os fracos, o agressor e suas vítimas (STEWART, 1999, p. 166-7). Esse era especialmente o caso quando o alvo da execução era um membro da elite dirigente. Nesse sentido, o apagamento 
da identidade do morto pela mutilação do rosto, o cortejo zombeteiro com o corpo mutilado e o despejo do cadáver em um rio, esgoto ou latrina eram todas formas de recusar ao condenado as honras fúnebres características da "bela morte" aristocrática e de apagar para sempre a sua memória do mundo dos vivos (HINARD, 1984, p. 308-310; sobre o conceito de "bela morte", ver VERNANT, 1982).

\section{UM CONTEXTO POLÍTICO TRANSFORMADO}

Constituído no âmbito da vida cívica e em relação às formas de justiça oficiais, o recurso ao linchamento continuaria a fazer parte do repertório de ações conhecido pelas populações das cidades mediterrâneas nos séculos IV e V. Seu impacto, porém, não poderia deixar de ser transformado pelo novo contexto político e cultural da Antiguidade Tardia.

A principal característica do governo do Império Romano a partir do século IV (e aquela que deveria afetar mais de perto as concepçôes e a prática da justiça popular nas cidades mediterrâneas) seria o reforço duradouro do poder central. No Império Romano Tardio, o imperador se tornou o centro de todas as atividades de governo (SILVA, 2003). Era ele quem controlava a política externa, a guerra e a paz, nomeava todos os funcionários, decretava os impostos, fazia as leis e exercia o poder de vida e morte sobre todos os seus súditos (JONES, 1964, p. 321-9). Na imaginação dos contemporâneos, a intervenção do imperador, para o bem e para o mal, era uma possibilidade sempre presente. Por conseguinte, era para a corte que os habitantes das províncias procuravam se voltar para resolverem de forma mais efetiva os seus problemas (KELLY, 1998, p. 155). Como em outros regimes absolutistas, os súditos do Império podiam atribuir mais facilmente as mazelas que afetavam suas vidas aos representantes do imperador do que ao próprio soberano, que, se fosse alertado (acreditava-se), não deixaria de intervir a seu favor (KELLY, 1998, p. 156).

O poder do imperador, no entanto, não teria se tornado tão pervasivo se não pudesse contar com um número muito maior de seus representantes e executores em todo o Império (BROWN, 1992, p. 9). Desde Diocleciano, a administração do Império foi confiada pelos imperadores a um corpo 
numeroso de funcionários de carreira livres, constituindo, a partir de seus níveis mais altos, uma nova e poderosa elite (LEPELLEY, 2001). As funçôes civis e militares dessa administração foram estritamente separadas e os efetivos militares, aumentados em relação aos séculos anteriores, passaram ao controle de uma cadeia independente de comando (LEE, 1998). Com a divisão das províncias em unidades menores e sua reorganização em dioceses e prefeituras, o número dos funcionários de carreira regulares associados aos escritórios de prefeitos, vicários e governadores também aumentou (HEATHER, 1998a, p. 204-5). Os governadores de província se tornaram mais presentes na vida das cidades, controlando as finanças e a administração municipal e julgando em primeira instância todas as causas civis e criminais (CARRIÉ, 1998, p. 21-25; HARRIES, 1999, p. 101). Com a multiplicação das cidades de residência do imperador e a nova jurisdição dos prefeitos do pretório, os tribunais de apelação também se tornaram muito mais próximos dos habitantes das províncias (BROWN, 1992, p. 11; HARRIES, 1999, p. 111).

Não há dúvida, portanto, de que o aumento espetacular da burocracia a serviço do imperador tornou o poder imperial muito mais presente na vida de seus súditos. Apesar disso, havia sempre o risco para os imperadores de que a presença nas províncias mais distantes de seus agentes em atividade e de outros funcionários aposentados que gozavam ainda da influência adquirida por sua ascensão na carreira imperial acabasse, ao contrário, por enfraquecer o poder central (BROWN, 1992, p. 9-17; KELLY, 1998, p. 138). Foi para tentar conter essas tendências centrífugas que os imperadores do século IV passaram a recorrer de maneira sistemática à intimidação e à violência contra seus próprios funcionários (MATTHEWS, 1989, p. 256-262) e é nesse contexto que nós devemos compreender o aumento vertiginoso do número de crimes punidos com a pena de morte. De 16 sob os Severos e 25 por volta de 200 d.C., o número de crimes passíveis de uma sentença capital passou a 35 por volta do ano 300 d.C. para chegar a 60 no final do governo de Constantino, enquanto que os próprios modos de execução também se tornaram muito mais violentos (MACMULLEN, 1986). Esse aumento da brutalidade judicial não foi, porém, indiscriminado. Como Jean-Michel Carrié e Aline Rousselle já ressaltaram, dos 25 
novos crimes passíveis da pena de morte instituídos por Constantino, 12 se referiam a faltas cometidas por funcionários:

Os novos crimes capitais são casos de corrupção e de extorsão por e para funcionários: juízes, procuradores das minas e oficinas imperiais, coletores de vectigalia, soldados estacionados que se permitem tomar os instrumentos de agricultura, coletores da anona, guardiães da prisão que maltratam os prisioneiros esperando julgamentos e não lhes permitem ver o sol a cada dia, monetários das oficinas imperiais que cunham falsa moeda, actores e procuradores da res privata infligindo maus tratos, juízes não respeitando os prazos de transmissão do poder central, funcionários de toda sorte exigindo contribuições dos proprietários de navios que são delas isentos. (CARRIÉ; ROUSSELLE, 1999, p. 345).

Como se vê, o aumento das penas capitais reflete antes de tudo a tentativa por parte do Estado imperial de controlar mais de perto os seus próprios funcionários, decretando um arsenal de penas dissuasivo (CARRIÉ; ROUSSELLE, 1999, p. 346). Em todos os casos, trata-se sempre de leis que visam a proteger os provinciais e que os encorajam a levarem suas queixas ao conhecimento do imperador.

O risco dessas leis, do ponto de vista do centro do poder, era que elas fossem compreendidas pelos habitantes das cidades do Mediterrâneo como um incentivo a agirem por conta própria, executando os funcionários que haviam cometido faltas condenadas pelo próprio imperador. Esse temor, como veremos, não era infundado. Independentemente da lealdade das multidōes ao imperador, o poder de desestabilização dessas ações era bastante real. Em muitos casos, a punição aos participantes de um linchamento podia até ser relevada pelas autoridades imperiais, por reconhecerem os custos da repressão ou as razões da revolta dos provinciais. Mas a morte de um funcionário não deixava de ter efeitos devastadores, ao colocar em risco a própria política imperial para uma cidade, uma província ou para toda uma região (BROWN, 1992, p. 105-110; HENCK, 2007). Linchamentos que representavam desafios flagrantes à autoridade imperial podiam, portanto, resultar em massacres, como os de Tessalônica, em 390 (Sozômeno, HE VII, 25), e Alexandria, em 457 (Zacarias de 
Mitilene, $H E$ IV, 9), ou, pelo menos, em outras formas não-letais de punição.

Como no passado, porém, os imperadores dos séculos IV e $\mathrm{V}$ ainda esperavam que açóes populares como essas pudessem ser evitadas pela colaboração dos notáveis municipais na manutenção da lei e da ordem em cada cidade (JACQUES, 1984, p. 374-404; BROWN, 1992, p. 78-89). No entanto, as cidades do Império Romano Tardio também haviam sido transformadas pelos efeitos conjugados da centralização do poder e da emergência dos conflitos religiosos, a partir da conversão de Constantino ao cristianismo. A abrupta afirmação do poder central agravou as divisões já existentes no seio das elites das cidades do Império, pela repartição desigual dos impostos, dos encargos e do acesso às dignidades imperiais (LEPELLEY, 2001). Esse fracionamento das elites citadinas, como já o disse Peter Brown, fez com que suas lutas internas aumentassem a partir do século IV, quando diferentes grupos passaram a derivar seu status e seu poder de fontes distintas: alguns ainda fundados apenas no pertencimento à cúria local; outros, amparados na colaboração estrita com o poder central e no exercício de cargos na carreira imperial (BROWN, 1992, p. 19). A emergência dos bispos cristãos como figuras de autoridade (GALVÃO-SOBRINHO, 2013) e as disputas entre diferentes grupos religiosos pelo controle do espaço urbano também fizeram com que a própria definição da comunidade citadina se tornasse, em muitas localidades, objeto de disputas (BROWN, 1992, p. 71-158; LIM, 1999). Num contexto em que as autoridades tradicionais se viram, com frequência, contestadas e em que as novas lideranças não hesitavam em mobilizar o poder das ruas para afirmar sua posição ou a força de seu grupo, os espaços e momentos para a intervenção popular foram ampliados. Também aqui, a execução informal por uma multidão ganhou uma nova dimensão, ao colocar em evidência as novas formas, mais ameaçadoras e mais efetivas, que havia tomado a intervenção popular nas lutas pelo poder no espaço urbano.

\section{Alvos, MOTIVAÇŌES E OPORTUNIDADES}

Os linchamentos que conhecemos para os séculos IV e $\mathrm{V}$ são todos indicadores desse contexto político mais turbu- 
lento. A maior parte das execuções informais mencionadas em nossas fontes tinham por alvo os representantes do poder central. Esse é o caso do mestre da cavalaria Hermógenes, em 342 (Amiano Marcelino, XIV, 10, 2; Sócrates, HE II, 13, 1-3); do governador da Síria, Teófilo, em 354 (Amiano Marcelino, XIV, 7, 5-6; Libânio, Or. 19, 46); do preposto monetário Dracônio e do comes Diodoro, mortos com o bispo Jorge de Alexandria, em 361 (Amiano Marcelino, XXII, 11, 3-11); do mestre da milícia Buterico, em 390 (Sozômeno, $H E$ VII, 25, 3); do prefeito da cidade de Roma, Pompeiano, em 409 (Gerôncio, Vita S. Mel. (G) 19); de um funcionário associado ao controle das taxas portuárias de Hipona, em 412 (Agostinho, S. 302 + Morin Guelf. 25), além, é claro, do comes Africae João, que vimos no início deste texto. $\mathrm{O}$ único imperador morto pelas mãos do povo, porém, é o imperador Petrônio Máximo, em 455, mas apenas por ter sido destituído de toda legitimidade aos olhos do povo por sua fuga durante o cerco de Roma pelos vândalos (Chron. Gall. a. 511 , n. 623). O segundo grupo mais citado em nossas fontes como vítimas de linchamentos são os militantes ou lideranças das facções em disputa pelo poder local. O exemplo mais conhecido é o da filósofa Hipátia, executada por partidários do bispo Cirilo por sua liderança entre a elite de Alexandria (Sócrates, HE VII, 15; João de Nikiu, 84, 100-102; Filostórgio, $H E$ VIII, 9, 9a). Pode-se ainda citar o caso de bispos como Marcelo de Apameia, na Síria, morto pelos habitantes pagãos de um vilarejo vizinho ao tentar destruir um templo (Sozômeno, HE VII, 15, 11-15), e dos militantes dissidentes no Norte da África, conhecidos em nossas fontes como "circuncelióes", que o próprio bispo católico Agostinho de Hipona reconhecia serem muitas vezes capturados por seus fiéis e executados de modo sumário, como bandidos (Agostinho, Ep. 88; SHAW, 2011, p. 710). Por fim, os bispos Jorge de Alexandria, em 361 (Amiano Marcelino, XXII, 11, 3-11; Sozômeno, $H E$ V, 7, 1-4; Sócrates, $H E$ III, 2-3), e Protério de Constantinopla, em 457 (Evágrio, HE II, 8; Zacarias de Mitilene, $H E$ IV, 1), podem ser vistos como representativos, ao mesmo tempo, dessas duas categorias de alvos de linchamentos: eram líderes de facções minoritárias em suas cidades, mas indicados e protegidos pelo imperador como representantes de sua política religiosa. 
Os motivos pelos quais os representantes do poder central são submetidos por uma multidão ao linchamento são exatamente os mesmos que, se provados em um processo legal, poderiam levá-los a serem condenados à pena capital: a extorsão dos provinciais, o abuso de poder e a negligência no cumprimento de suas funções. O governador Teófilo, em Antioquia, em 354 (Amiano Marcelino, XIV, 7, 5-6), o prefeito Pompeiano, em Roma, em 409 (Gerôncio, Vita S. Mel. (G) 19), como mais tarde o prefeito do Egito Teodósio, em Alexandria, em 515 ou 516 (Malalas 401 [XVI, 15]), são todos executados pela multidão por serem vistos como responsáveis pela escassez de alimentos. O funcionário morto por uma multidão em Hipona, em 412, e que os fiéis de Agostinho acusavam de ter a muitos reduzido "à mendicância e à pobreza”, era um responsável pelo controle dos movimentos no porto e da arrecadação de taxas alfandegárias que, em colaboração com os coletores, extorquia mercadores e artesãos (Agostinho, S. 302 + Morin Guelf. 25; MAGALHÃES DE OLIVEIRA, 2012, p. 275-297). O bispo Jorge, do mesmo modo, havia suscitado a cólera da multidão em Alexandria não apenas por ter feito entrar as tropas do dux do Egito na cidade para destruir templos e reprimir seus adeptos, mas também por ter extorquido e levado denúncias contra os habitantes da cidade ao conhecimento do imperador (Amiano Marcelino, XXII, 11, 3-11; Juliano, Ep. 21 = Sócrates, $H E$ III, 3, 4-25). O ressentimento causado pela presença e pelos abusos dos militares entre a população civil é também o motivo subjacente aos linchamentos de um soldado godo de Constantinopla, nos anos 380 (Libânio, Or. XIX, 22 e Or. XX, 14), e do mestre da milícia Buterico em Tessalônica, em 390 (Sozômeno, HE VII, 25, 3), em ambos os casos uma decorrência da política militar do imperador Teodósio de utilizar soldados godos para defender a parte oriental do Império (HEATHER, 1998b, p. 509-10). No contexto dos conflitos sectários, porém, os motivos que conduziam com mais frequência ao linchamento de funcionários imperiais, lideranças locais e militantes eram a resistência ao uso da força e a retaliação por agressões passadas praticadas contra pessoas ou objetos de culto. Esse é o caso não apenas do bispo ariano Jorge, do preposto monetário Dracônio e do comes Diodoro, atacados pelos pagãos de Alexandria em 361, ou do bispo calcedoniano Protério, em 457, morto por seus 
adversários cristãos num acerto de contas pela opressão sofrida no passado (GREGORY, 1979, p. 181-192), mas também do mestre da cavalaria Hermógenes que, enviado em 342 pelo imperador Constâncio II para exilar o bispo niceno Paulo, encontra uma inesperada resistência dos fiéis que, ao serem atacados em sua igreja, revidam invadindo e incendiando sua casa e arrastando-o pelas ruas até a morte (Amiano Marcelino, XIV, 10, 2; Sócrates, HE, II, 13, 1-3; HENCK, 2007, p. 153; GALVÃO-SOBRINHO, 2013, p. 142).

As ocasiōes específicas que favorecem a ocorrência de um linchamento são variadas, mas implicam sempre uma avaliação por parte dos participantes não apenas das possibilidades de sucesso ou fracasso de sua ação, mas também de sua urgência. Dentre os episódios reportados em nossas fontes, é possível distinguir, em um extremo do espectro, os linchamentos em que os participantes podiam se ver justificados pelo apoio de uma liderança ou do próprio imperador. Em Antioquia, em 354, a morte do governador Teófilo pode, assim, ser atribuída ao próprio César Galo, que, ao responsabilizar publicamente o governador pela escassez de alimentos, fez com que a multidão o atacasse, nas palavras de Amiano Marcelino (XIV, 7, 6), "como se ele tivesse sido entregue por um julgamento imperial”. O assassinato de Hipátia, em 415, e do bispo Protério, em 457, não contam com um apoio imperial, mas seus participantes podem ter sido incentivados por uma liderança local: no primeiro caso, pelo bispo Cirilo ou, pelo menos, por seu leitor Pedro, que também era um magistrado de Alexandria (Damáscio, V. Isidori, frag. 105; Sócrates, HE VII, 15; João de Nikiu 84, 100); no segundo, pelo bispo Timóteo, uma vez que o linchamento ocorre no momento em que este recuperava pela força a basílica e o palácio episcopal ocupados por Protério (Evágrio, HE II, 8). Em todos esses casos, a condição estrutural para a intervenção popular são as profundas divisões na elite. Em Antioquia, em 354, essas divisões favorecem a aliança entre os interesses da plebe e os da corte de Galo (MATTHEWS, 1989, p. 406-8). Em Alexandria, em 415, a constante oposição entre o prefeito Orestes e o bispo Cirilo (e a divisão dos membros da cúria local entre um lado e outro da disputa) é o que mobiliza o apoio ao linchamento de Hipátia, alimentado pelos boatos de que ela seria a responsável por impedir a reconciliação entre os adversários e 
2. Populus: Agostinho, $S$. 302, 20; Chron. Gall. a. 452, n. 59, 15. Vulgus: Amiano Marcelino, XIV, 7, 6 (unlgus sordidior); Chron. Gall. a. 511, n. 623 (tumultu uulgi). Multitudo: Agostinho, S. Guelf. 25 (indisciplinata multitudo). Plebs: Amiano Marcelino, XIV, 7, 5 (plebs Antiochensis); Id., XXII, 11 (plebs omnis). Popularium turbela: Amiano Marcelino, XIV, 10, 2 (popularium ... turbela discerpit). $\Lambda \alpha$ $\varsigma$ : Sócrates, HE VII, 15, 4.

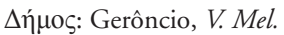

(G) 19; Sozômeno, $H E$

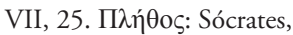

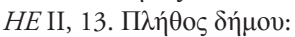

Evágrio, $H E$ II, 8. Sobre o vocabulário atestando o amplo envolvimento popular nesta e em outras formas de ação coletiva no período, ver MacMullen (2003, p. 487, n. 55), contra McLynn (1992, p. 34). liderar a oposição da elite alexandrina ao bispo Cirilo (HAAS, 1997, p. 295-316). A ocasião para um linchamento também podia se configurar com a percepção ou a esperança de uma mudança nos alinhamentos políticos. Não é por acaso que os linchamentos dos bispos Jorge e Protério ocorrem após o anúncio da morte do imperador que os favorecia (Sozômeno, $H E$ V, 7, 2: anúncio da morte de Constâncio II; Evágrio, $H E$ II, 8: anúncio da morte de Marciano). Com efeito, o momento do acerto de contas é, muitas vezes, o do abrandamento da repressão. Mas esse nem sempre é o caso. No extremo oposto desse espectro de possibilidades, o linchamento também podia se configurar como um desafio aberto às forças de repressão, às autoridades constituídas e ao próprio imperador. $\mathrm{O}$ desafio podia resultar da percepção de que a autoridade atacada havia perdido toda legitimidade (como ocorre com o prefeito Pompeiano e o imperador Petrônio Máximo durante dois cercos de Roma: Gerôncio, V. Mel. (G) 19; Chron. Gall. a. 511, n. 623). Em outros casos, porém, era a ameaça à sobrevivência do grupo que se sobrepunha ao risco de sua ação, como vemos no caso do mestre da cavalaria Hermógenes, atacado e morto pelos partidários do bispo Paulo ao tentar cumprir uma ordem imperial. Por fim, a urgência de uma execução sumária também se torna o fator mais importante para a ocorrência de um linchamento quando o alvo da cólera popular parece escapar à justiça oficial: esse é o caso do funcionário retirado de seu refúgio na basílica de Hipona, em 412, pelos habitantes que temiam vê-lo escapar à sua punição (Agostinho, $S$. Guelf. 25) e também do bispo Jorge que, após ser entregue às autoridades pela própria multidão, é, dias depois, retirado da prisão para ser morto pelos mesmos amotinados (Sozômeno, $H E \mathrm{~V}, 7,2-3)$.

\section{VARIEDADES DE MULTIDŌES}

As multidões que executam esses linchamentos são sempre apresentadas em nossas fontes como o populus, o uulgus, a multitudo, a popularium turbela, a plebs omnis, em latim, ou

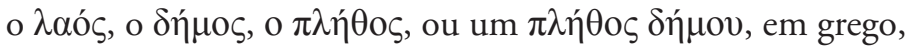
o que implica a percepção dos autores antigos de uma ampla participação popular. ${ }^{2}$ Gangues mais restritas, como os circunceliōes na África (SHAW, 2011, p. 675-720) e os parabalani 
em Alexandria (HAAS, 1997, p. 314), são muitas vezes acusadas de vários atos de violência, como espancamentos e atentados, mas nunca de exercer uma execução sumária segundo os rituais da justiça popular. É verdade que a natureza de nossa documentação, constituída por cartas, discursos, histórias e crônicas, não nos permite vislumbrar com maior precisão "os rostos da multidão", para citar a expressão de George Rudé (2005, p. 195-213). Mesmo assim, é possível identificar, para além do vocabulário, alguns indícios de variaçôes na composição e organização dessas multidões.

Fora das cidades, o linchamento podia envolver a maioria dos habitantes de um vilarejo num ato de solidariedade defensiva contra um estrangeiro, como o bispo Marcelo de Apameia, na Síria, os três padres cristãos mortos pelos aldeões pagãos do Val di Non, na Itália, ou os missionários católicos executados pelos habitantes do vilarejo donatista de Fussala, na África (Sozômeno, HE VII, 15, 11-15; Virgílio de Trento, Epp. 1-2; Agostinho, Ep. 209, 2; cf. FRANKFURTER, 1998, p. 70). Nas grandes cidades, mesmo uma participação massiva envolvia grupos mais específicos e solidariedades prévias. Em Hipona, em 412, como já pude argumentar em outra ocasião, um sermão de Agostinho destinado a repreender os fiéis que haviam tomado parte no linchamento de um funcionário imperial associado à coleta de taxas alfandegárias nos permite identificar, entre os participantes da revolta, alguns dos mercadores em atividade no porto e seus servidores, além de artesãos e lojistas que dependiam do comércio marítimo para o que compravam ou vendiam e dos jovens de suas famílias (Agostinho, S. 302 + Morin Guelf. 25; MAGALHĀES DE OLIVEIRA, 2012, p. 275-297). Em Antioquia, em 354, o ataque ao governador Teófilo no hipódromo é liderado, segundo Libânio (Or. XIX, 47), por cinco jovens trabalhadores metalúrgicos, talvez associados às fábricas imperiais, enquanto que outros participantes condenados à morte na repressão que se seguiu são identificados por Amiano Marcelino apenas como pauperes (MATTHEWS, 1989, p. 406-8). Em casos como esses, por mais ampla que fosse a coalização reunida pelo ódio a um inimigo comum, as multidôes que praticavam o linchamento não dependiam de nenhuma organização prévia, mas apenas do conhecimento prático dos princípios subjacentes a esse tipo de ação e, talvez, de laços de grupo 
ou comunidade anteriores. O próprio cenário do ataque é, nesses casos, um local habitual de reunião, como o hipódromo em que Teófilo, em Antioquia, e Buterico, em Tessalônica, são atacados, ou ainda uma aglomeração espontânea gerada pela chegada de uma notícia inesperada, como o refúgio do funcionário odiado pelos habitantes de Hipona na igreja de Agostinho ou a descoberta do imperador Petrônio Máximo em fuga diante das portas de Roma.

Em outras circunstâncias, porém, um linchamento podia apresentar sinais mais claros de organização e premeditação. Esse é o caso, sobretudo, da morte de Hipátia que, segundo Sócrates ( $H E$ VII, 15), havia resultado de uma verdadeira conspiração. A decisão de eliminar Hipátia surge no contexto das lutas entre o prefeito Orestes e o bispo Cirilo, quando um boato começa a circular entre a plebe cristã de que a filósofa seria a responsável por organizar a oposição ao bispo e impedir a reconciliação entre as partes. Um grupo organizado

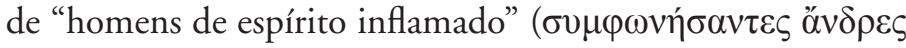

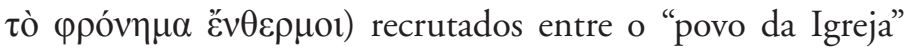

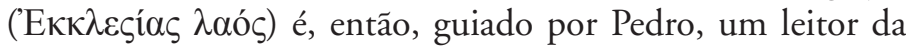
igreja e magistrado municipal, para armar uma emboscada e atacar Hipátia em sua carruagem quando essa chegava em sua casa (Sócrates, $H E$ VII, 15, 4-5. Cf. João de Nikiu, 84, 100). Não há dúvida, portanto, de que se tratava, nesse caso, de uma ação cuidadosamente orquestrada. Mas é significativo que, apesar das suspeitas dos historiadores modernos de um envolvimento em sua morte dos temíveis parabalani (enfermeiros sob o comando do bispo de Alexandria e que serviam de tropa de choque em sua defesa), não haja nenhuma confirmação nas fontes antigas de sua participação. É verdade que, nos dias que se seguiram ao assassinato de Hipátia, Cirilo não hesitaria em utilizar sua gangue para aterrorizar os curiais que lhe faziam oposição, invadindo e perturbando as reuniōes da cúria. Mas nenhuma das leis editadas pelo poder imperial entre $416 \mathrm{e}$ 418 para repreender o patriarca de Alexandria e regular as atividades dos parabalani (como CTh XVI, 2, 42, 2) menciona o assassinato como uma de suas atividades condenadas. Além disso, como Christopher Haas já observou, um envolvimento direto dos parabalani teria resultado numa acusação formal de assassinato contra o patriarca, do qual eles dependiam diretamente. Ao contrário, uma multidão de laicos liderada por 
um magistrado podia mais facilmente se apresentar como representante da vontade popular (HAAS, 1997, p. 313-5). O próprio recurso ao linchamento, segundo os ritos da justiça popular, demonstra que essa era, de fato, a intenção de seus executores.

\section{OS RITOS DA “MORTE JUSTA”}

O linchamento, enquanto forma estritamente ritualizada de violência coletiva, envolve sempre códigos específicos de conduta e modelos conhecidos de ação (TILLY, 2003, p. 14). Como tal, ele tem sempre uma enorme ressonância cultural, pois se trata de uma performance pela qual um grupo reivindica a legitimidade de sua ação, afirmando concepções particulares de autoridade e de justiça popular (PFEIFER, 2004, p. 44-9). Apesar da variedade de multidóes que podiam recorrer a essa forma de violência, os rituais de execução na Antiguidade Tardia, apresentavam, ainda que com variantes locais, uma notável regularidade num espaço mediterrâneo há muito unificado pelo Império. À exceção das ações dos aldeões do Val di Non e dos habitantes de um vilarejo dependente de Apameia, que executam suas vítimas queimando-as vivas (Virgílio de Trento, Epp. 1-2; Sozômeno, HE VII, 15, 14), os linchamentos reportados em nossas fontes, mesmo nas cidades do oriente, são sempre executados, segundo a tradição romana, não pelo apedrejamento, mas "pelas mãos do povo". É assim que Hermógenes, em Constantinopla, é "esquartejado por uma turba do povo" (Amiano Marcelino, XIV, 10, 2: popularium ... turbela discerpit); o governador Teófilo é "atacado com socos e pontapés, pisoteado e mutilado ainda meio vivo e esquartejado de modo miserável" (Amiano Marcelino, XIV, 7, 6: calcibus incessens et pugnis, conculcans seminecem laniatu miserando discerpsit); o bispo Jorge em Alexandria é "calcado aos pés" e "esquartejado" (Amiano Marcelino, XXII, 11, 8: conculcans diuaricatis pedibus interfecit, Juliano, Ep. 21, 380a

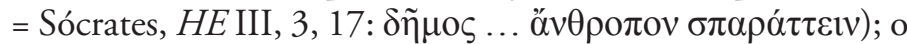
prefeito Pompeiano, em Roma, é "coberto de feridas e massacrado no centro da cidade" (Gerôncio, V. Mel. (G) 19: ovi $\tau \omega \varsigma$

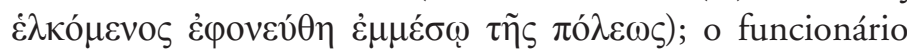
excutado pelos habitantes de Hipona é, segundo Agostinho (S. 302, 10), seviciado "até a morte ... e mesmo após a morte" 
(saeuit usque ad mortem ... et post mortem), e a própria Hipátia, levada até a igreja do Kaisarion em Alexandria, é despida e esquartejada até a morte com cacos de cerâmica (Sócrates, $H E$

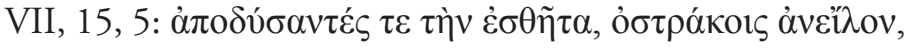

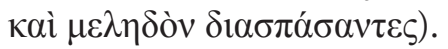

Nas narrativas mais detalhadas é ainda possível identificar outras constantes nesses rituais de execução: as zombarias e injúrias vocais endereçadas à vítima, o corpo arrastado ou transportado em cortejo pelas ruas e os restos mortais cremados ou jogados em um rio ou no mar. Em Alexandria, os corpos mutilados de Jorge, Dracônio e Diodoro, em 361, de Hipátia, em 415, e de Protério, em 457, são expostos ao ridículo por toda a cidade. No primeiro caso, as vítimas são transportadas no dorso de camelos até a praia, onde seus restos são cremados para depois serem jogados ao mar (Amiano Marcelino, XXII, 11, 10; Sócrates, $H E$ V, 7, 3 e Sozômeno, III, 2, 10). No caso de Hipátia, seu corpo é arrastado pelas ruas e levado até um lugar chamado Kinarion onde é incinerado (Sócrates, $H E$ VII, 15). Por fim, o corpo transpassado de Protério é primeiro exposto numa forca, depois arrastado por toda a cidade em meio a zombarias, e, por fim, esquartejado membro por membro antes de ser cremado (Evágrio, HE II, 8). Em Constantinopla, Antioquia ou Hipona, os corpos de Hermógenes, Teófilo e um funcionário também são mutilados e arrastados pelas ruas (Sócrates, II, 13; Libânio, Or. XIX, 46; Agostinho, S. 302, 10), enquanto que um soldado godo em Constantinopla e o imperador Petrônio Máximo em Roma têm seus restos mortais jogados respectivamente no mar e no rio Tibre (Libânio, Or. XIX, 22 e XX, 14; Próspero de Aquitânia, Epit. Chron. a. 455, 1375).

O caráter ritual de todas essas execuções expressava sempre, de forma implícita, uma reivindicação, por parte do grupo que o praticava, de agir em nome do povo, afirmando o direito de iniciativa dos cidadãos e sua obrigação de punir e purgar a comunidade de seus inimigos. Noções como essas transparecem, a contrapêlo, nas admoestaçõos feitas aos participantes de um linchamento por autores tão diferentes como o imperador pagão Juliano e o bispo cristão Agostinho. Escrevendo aos alexandrinos após a morte de Jorge, Juliano, ainda que reconhecendo que o bispo merecia ser castigado, respondia aos argumentos que legitimavam a ação popular: 
Um povo ousa, como cães, despedaçar um homem e, depois, não tem vergonha de aparesentar aos deuses suas mãos ensanguentadas, como se estivessem puras! "Mas Jorge merecia sofrer um tal tratamento". E talvez ainda um tratamento pior e mais cruel, eu diria. "Por causa de nós", dirieis vós. Eu também estou de acordo. Mas se dizeis "por nós”, com isso não posso mais concordar. Temos leis que devem ser honradas e amadas por todos e cada um em particular. Mas quando acontece de indivíduos a infringirem, é preciso ao menos que a comunidade seja regida pela lei, que obedeçamos às leis e que não venhamos a transgredir o que foi legislado com razão desde o princípio (Juliano, Ep. 21, 380a-380b = Sócrates, $H E$ III, 3, 17-19). ${ }^{3}$

Quanto a Agostinho, era em termos semelhantes que o bispo contestava as alegações de seus fiéis que haviam tomado parte em um linchamento:

Por que te assanhas com furor contra os maus? "Porque são maus", respondes. Tu te juntas a eles, enfurecendo-te contra eles. [...] Depois, tu te encarniças com furor até a morte. Mas por que também depois da morte, quando aquele mau não sofre mais nenhum castigo e apenas quem o agride exerce sua maldade? Isso é praticar a loucura, não a vingança. [...] "Mas esse malvado fez tantas coisas, a tantos oprimiu, a tantos reduziu à mendicância e à pobreza”. Ele tem os seus juízes, ele tem as autoridades constituídas. [...] E tu, por que te enfureces? Que poder recebeste? Não sabes que isso não é um suplício público, mas um verdadeiro banditismo? [...] Nós não dizemos que o malvado não seja malvado. Mas ele deve prestar contas àquele que deve julgá-lo. Por que queres assumir a responsabilidade pela morte de outra pessoa, tu que não carregas o fardo da autoridade? Deus te livrou do fardo do juiz: por que usurpas o que não te pertence? (Agostinho, S. 302, 10 e 13). ${ }^{4}$

Em ambos os casos, o que o imperador e o bispo vêem como uma usurpação da lei e do poder constituído, é apenas, para os participantes do linchamento, o cumprimento devido da justiça, uma "execução pública” de um inimigo público e, em última instância, um poder do povo. Nas palavras dos
3. Тo $\lambda \mu \tilde{\alpha} \delta \tilde{\eta} \mu \circ \varsigma \tilde{\sigma} \sigma \varepsilon \rho$ oi

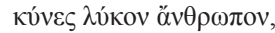

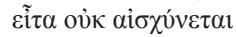

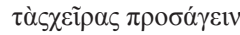

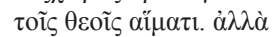

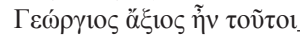

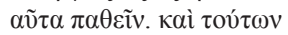

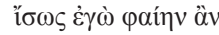

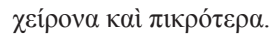

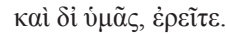

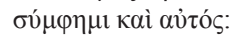
$\pi \alpha \rho ่$ v $\mu \tilde{\omega} \nu \delta \dot{\varepsilon} \varepsilon \dot{\imath} \lambda \varepsilon \dot{\varepsilon} \gamma \mathrm{O} \tau \varepsilon$,

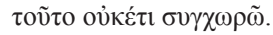

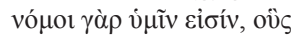

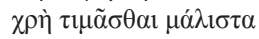

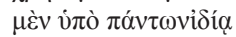

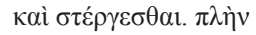
$\dot{\varepsilon} \pi \varepsilon 1 \delta \grave{~} \sigma v \mu \beta \alpha i ́ v \varepsilon 1 \tau \tilde{\omega} v$

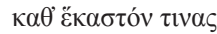
$\pi \alpha \rho \alpha v o \mu \varepsilon \tilde{v} v, \dot{\alpha} \lambda \lambda \dot{\alpha} \tau \grave{\alpha}$

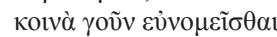

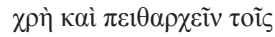

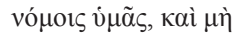

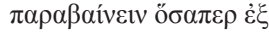
$\dot{\alpha} \rho \chi \tilde{\eta} \varsigma \dot{\varepsilon} \vee \rho \mu i ́ \sigma \theta \eta \kappa \alpha \lambda \tilde{\omega} \varsigma$.

4. Quid saeuis in malos? Quia mali sunt, inquis. Addis te illis, saeuiendo in illos. [...] Postremo saeuit usque ad mortem. Quid et post mortem, ubi ad illum malum iam non peruenit poena, et alterius mali sola exercetur malitia? Hoc insanire est, non uindicare. [...] Sed malus ille tanta fecit, tantos oppressit, tantos ad mendicitatem egestatemque perduxit. Habet iudices suos, habet potestates suas. [...] Tu quare saeuis? Quam potestatem accepisti, nisi quia sunt ista non publica supplicia, sed aperta latrocinia? [...] Non enim malos defendimus, aut dicimus malos non esse malos. Reddent inde rationem qui iudicant. Quare de morte aliena tu uis reddere difficultatem rationis, qui non portas sarcinam potestatis? Liberauit te deus, ut non sis iudex: quid tibi usurpas alienum? 
habitantes de Hipona, reportadas por Agostinho (S. 302, 20): Quod populus fecerit, fecit! "O que o povo fez, feito está!"

As noçôes de direitos do populus ou do $\delta \eta \dot{\mu}$ os que justificavam afirmações como essa tinham, como vimos, uma longa tradição. O que havia de novo na Antiguidade Tardia era apenas a audácia da multidão identificada por Agostinho e Juliano, a sua capacidade renovada de ultrapassar os espaços e momentos de atuação definidos pelas autoridades. De fato, no contexto politicamente mais turbulento de nosso período, as antigas noções de cidadania e de direitos do povo e a ideia mesma de "morte justa" aplicada a um inimigo público não haviam desaparecido, mas ganharam novos (e mais ameaçadores) significados. $\mathrm{O}$ linchamento torna-se, nesse sentido, um fenômeno bastante complexo, na confluência entre as tradições de justiça popular e a luta política.

\section{Agradecimentos}

Agradeço a Pedro Paulo Funari e Luciane Omena pelo convite para escrever este artigo, a Carlos Galvão-Sobrinho e Rafael Monpean, pelas indicações bibliográficas e pelas discussões de ideias aqui expostas, e por fim, mas não menos importante, a Priscila Nunes, pela leitura de uma versão preliminar deste texto e pelo apoio de sempre. Os argumentos defendidos e os erros subsistentes são de inteira responsabilidade do autor.

\section{REFERÊNCIAS BIBLIOGRÁFICAS}

BROWN, P.. Power and Persuasion in Late Antiquity: Towards a Christian Empire. Madison: University of Wisconsin Press, 1992.

CARRIÉ, J.-M.. Le gouverneur romain à l'époque tardive. Les directions possibles de l'enquête. AnTard, Turnhout, v. 6, p. 17-30, 1998.

CARRIÉ, J.-M.; ROUSSELLE, A.. L'Empire romain en mutation: des Sévères à Constantin (192-337). Paris: Éditions du Seuil. (Nouvelle histoire de l'Antiquité, 10), 1999.

COLEMAN, K. M.. Fatal charades: Roman executions staged as mythological enactments. JRS, v. 80, p. 44-73, 1990. 
CORBIN, A.. Les villages des cannibales. Paris: Aubier, 1990.

DAVID, J.-M.. Du Comitium à la roche Tarpéienne. Sur certains rituels d'exécution capitale sous la République, les règnes d'Auguste et de Tibère. In: Du châtiment dans la cité. Supplices corporels et peine de mort dans le monde antique. (Table ronde de Rome 9-11 novembre 1982). Rome: École Française de Rome, p. 131-176. (CÉFR, 79), 1984.

DAVIS, N. Z.. Ritos de violência. In: . Culturas do Povo. Sociedade e cultura no início da França moderna: oito ensaios. Trad. de Mariza Corrêa. Rio de Janeiro: Paz e Terra, p. 129-156, 1990.

DELMAIRE, R. ; LEPELLEY, C.. Du nouveaux sur Carthage: le témoignage des lettres de saint Augustin découvertes par Johannes Divjak. Opus, Roma, v. 2, p. 473-485, 1983.

DZIELSKA, M.. Hypatia of Alexandria. Transl. F. Lyra. Cambridge, Mass.: Harvard University Press, 1996.

FAGAN, G. G.. Violence in Roman social relations. In: PEACHIN, M. (Ed.). The Oxford Handbook of Social Relations in the Roman World. Oxford: Oxford University Press, p. 467-495, 2011.

FORSDYKE, S.. Street theatre and popular justice in Ancient Greece: shaming, stoning and starving offenders inside and outside the courts. Past and Present, v. 201, p. 3-50, 2008.

FRANKFURTER, D.. Religion in Roman Egypt: Assimilation and Resistance. Princeton, NJ: Princeton University Press, 1998.

GALVÃO-SOBRINHO, C. R.. Doctrine and Power: Theological Controversy and Christian Leadership in the Later Roman Empire. Berkeley: University of California Press, 2013.

GRAS, M.. Cité grecque et lapidation. In: Du châtiment dans la cité. Supplices corporels et peine de mort dans le monde antique. (Table ronde de Rome 9-11 novembre 1982). Rome: École Française de Rome, p. 75-89. (CÉFR, 79), 1984.

GREGORY, T. Vox Populi: Violence and Popular Involvement in the Religious Controversies of the Fifth Century AD. Columbus: Ohio State University Press, 1979.

HAAS, C.. Alexandria in Late Antiquity: Topography and Social Conflict. Baltimore: The Johns Hopkins University Press, 1997. 
HAHN, J.. Gewalt und religiöser Konflikt. Studien zu den Auseinandersetzungen zwischen Christen, Heiden und Juden im Osten des Römischen Reiches (von Konstantin bis Theodosius II). Berlin: Akademie Verlag. (Klio Beihefte N.F. 8), 2004.

HARRIES, J.. Law and Empire in Late Antiquity. Cambridge: Cambridge University Press, 1999.

HARRIES, J.. Law and Crime in the Roman World. Cambridge: Cambridge University Press, 2007.

HEATHER, P.. Senators and senates. In: CAMERON, Av.; GARNSEY, P. (Eds.). The Cambridge Ancient History XIII: The Late Empire, AD 337-425. Cambridge: Cambridge University Press, p. 184-210, 1998a.

HEATHER, P.. Goths and Huns, c. 320-425. In: CAMERON, Av.; GARNSEY, P. (Eds.). The Cambridge Ancient History XIII: The Late Empire, AD 337-425. Cambridge: Cambridge University Press, p. 487-515, 1998 b.

HENCK, N.. Constantius II and the Cities. In: DRINKWATER, J.; SALWAY, B. (eds.). Wolf Liebeschuetz Reflected: Essays Presented by Colleagues, Friends, and Pupils. London: Institute of Classical Studies, School of Advanced Study, University of London, p. 147-156, 2007.

HINARD, F. La male mort. Exécutions et statut du corps au moment de la première proscription. In: $D u$ châtiment dans la cité. Supplices corporels et peine de mort dans le monde antique. (Table ronde de Rome 9-11 novembre 1982). Rome: École Française de Rome, p. 295-311. (CÉFR, 79), 1984.

JACQUES, F. Le privilège de liberté. Roma: École Française de Rome, 1984.

JONES, A. H. M.. The Later Roman Empire (284-602): A Social, Economic and Administrative Survey. Oxford: Blackwell, 1964.

JONES, A. H. M.; MARTINDALE, J. R.; MORRIS, J.. The Prosopography of the Later Roman Empire. V. 2. Cambridge: Cambridge University Press, 1980.

KELLY, C.. Emperors, government and bureaucracy. In: CAMERON, Av.; GARNSEY, P. (Eds.). The Cambridge Ancient History XIII: The Late Empire, AD 337-425. Cambridge: Cambridge University Press, p. 138-183, 1998. 
LAVAN, L.. The end of the temples: Towards a new narrative? In: LAVAN, L.; MULRYAN, M. (Eds.). The Archaeology of Late Antique "Paganism". Leiden: Brill, p. xv-lxv, 2011.

LEE, A. D.. The army. In: CAMERON, Av.; GARNSEY, P. (Eds.). The Cambridge Ancient History XIII: The Late Empire, AD 337-425. Cambridge: Cambridge University Press, p. 211-237, 1998.

LEPELLEY, C.. La carrière municipale dans l'Afrique romaine sous l'Empire tardif. In: Aspects de l'Afrique romaine. Les cités, la vie rurale, le christianisme. Bari: Edipuglia, p. 105-124. (Munera, 15), 2001.

MACMULLEN, R.. Judicial savagery in the Roman Empire. Chiron, v. 16, p. 147-166, 1986.

MACMULLEN, R.. Cultural and political changes in the $4^{\text {th }}$ and $5^{\text {th }}$ centuries. Historia, Berlin, v. 52, n. 4, p. 465-495, 2003.

MAGALHÃES DE OLIVEIRA, J. C.. Potestas Populi: Participation populaire et action collective dans les villes de l'Afrique romaine tardive (vers 300-430 apr. J.-C.). Turnhout: Brepols. (Bibliothèque de l'Antiquité Tardive, 24), 2012.

MATTHEWS, J.. The Roman Empire of Ammianus. Baltimore: The Johns Hopkins University Press, 1989.

MCLYNN, N.. Christian controversy and violence in the fourth century. Kodai, Tóquio, v. 3, p. 15-44, 1992.

NIPPEL, W.. Public Order in Ancient Rome. Cambridge: Cambridge University Press, 1995.

PFEIFER, M. J.. Rough Justice: Lynching and American Society, 1874-1947. Urbana; Chicago: University of Illinois Press, 2004.

RIVIÈRE, Y.. Pouvoir impérial et vengeance : De Mars ultor à la diuina uindicta (I ${ }^{\text {er-IVe }}-\mathrm{VV}^{\mathrm{e}} \mathrm{cles}$ apr. J.-C.). In: BARTHÉLEMY, D.; BOUGARD, F.; LE JAN, R. (Eds.). La vengeance, 400-1200. Roma: École Française de Rome, p. 7-42. (CÉFR, 357), 2006.

ROSIVACH, V. J.. Execution by stoning in Athens. Classical Antiquity, Berkeley, v. 6, n. 2, p. 232-248, 1987.

RUDÉ, G.. The Crowd in History: A Study of Popular Disturbances in France and England, 1730-1848. London: Serif [1964], 2005. 
SHAW, B. D.. Sacred Violence: African Christians and Sectarian Hatred in the Age of Augustine. Cambridge: Cambridge University Press, 2011.

SILVA, G. V.. Reis, santos e feiticeiros: Constâncio II e os fundamentos místicos da basiléia (337-361). Vitória: Edufes, 2003.

STEWART, P.. The destruction of statues in late antiquity. In: MILES, R. (Ed.). Constructing Identities in Late Antiquity. London; New York: Routledge, p. 159-189, 1999.

TILLY, C.. The Politics of Collective Violence. Cambridge, UK: Cambridge University Press, 2003.

VERNANT, J.-P.. La belle mort et le cadavre outragé. In: GNOLI, G.; VERNANT, J.-P. (Eds.). La mort, les morts dans les sociétés anciennes. Cambridge, UK: Cambridge University Press; Paris: Éditions de la Maison des Sciences de l'Homme, p. 45-76, 1982.

WALDREP, C.. The Many Faces of Judge Lynch: Extralegal Violence and Punishment in America. New York: Palgrave MacMillan, 2002.

WATTS, E.. The murder of Hypatia: Acceptable or unacceptable violence? In: DRAKE, H. A. (Ed.). Violence in Late Antiquity: Perceptions and Practices. Alershot: Ashgate, p. 333342, 2006.

WIEDEMANN, T.. Emperors and Gladiators. London; New York: Routledge, 1992.

Recebido em março de 2014. Aprovado em julho de 2014. 